\title{
App-solutt anbefalt
}

\author{
Helt siden jeg fikk min første smarttelefon for tre år siden har jeg vært på grensen til lidenskapelig interessert \\ i medisinske apper til bruk i min hverdag som medisinstudent.
}

Appene lastes ved et par trykk enkelt ned til telefonen, koster som regel bare noen tiere og er enkle i bruk. De kan stimulere til læring eller fungere som et rent oppslagsverk.

Jeg har prøvd mange apper de siste tre årene, men har likevel ikke vært innom en brøkdel av det som finnes på markedet. Per i dag har jeg ikke kontroll på hvor mange hundre tusen medisinske apper man kan få tak i, da tallet øker hver eneste dag.

Til tross for at jeg har muligheten til det har jeg i forbindelse med denne teksten ikke undersøkt hvor mange tusen kroner jeg har brukt på apper. Det vil antageligvis være sørgelig mye, da terskelen for å slette en app og kjøpe en annen for en tier, er svært lav. Dessverre er det nemlig slik at mange apper har en god utgangsidé og reklametekst - men fungerer ikke i praksis. I hvert fall ikke for min del.

Jeg vil i denne teksten trekke frem noen av mine favoritter og konsentrere meg om de jeg faktisk har bruk for i min studiehverdag. Erfaringene er basert på bruk med iPhone 4 og iPhone 5, men mange av appene finnes også til Android-telefoner.

Jeg har valgt å dele erfaringene og anbefalingene mine inn i to grupper: lceringsverktøy og referanseverktøy. Grunnen til denne inndelingen er at jeg har erfart at man bruker medisinske apper på to litt forskjellige måter: en for å tilegne seg ny kunnskap (spill, puggeapplikasjoner, veiledere osv.) og en for å slå opp fakta (medikamentdosering, diagnosekoder osv.).

\section{Læringsapper}

Disse appene bruker jeg når jeg ønsker å lære meg noe nytt i et ledig øyeblikk, for eksempel på bussen på vei hjem.

- Prognosis - your diagnosis: Dette er den mest inspirerende medisinske appen jeg har prøvd - et morsomt spill med deg som diagnostiserende lege. Du kan foreløpig velge mellom litt over 100 forskjellige pasientkasus innenfor medisin, kirurgi, gynekologi og pediatri. Du får presentert symptomene til pasienten (en tegneseriefigur), bestemmer hvilke aktuelle undersøkelser du gjør, får svarene på disse og velger behandling. Til slutt får du en samlet skår, en forklaring på hva du burde gjort, og hvorfor - i tillegg til en grundig og kvalitetssikret gjennomgang av tilstanden pasienten hadde. Alt dette er pakket inn i en grafisk fin og intuitiv pakke - og appen er attpåtil gratis. Løp og last ned!
- Quiz i Medicin og Kirurgi: Denne danske appen, som stammer fra læreboken Basisbog i Medicin og Kirurgi, er en helt enkel quizapp som rett og slett stiller deg generelle medisinske spørsmål. Det finnes utallige slike apper, men grunnen til at jeg liker akkurat denne er fordi den er skrevet på lettfattelig dansk, fordi man enkelt kan velge organsystemer (perfekt om det nærmer seg eksamen i for eksempel urologi) og fordi du ytterligere kan snevre inn spørsmålsbanken til bare diagnoser, bare behandlingsprinsipper eller alle. Utvalget av spørsmål er enormt. Denne er dog i dyreste laget.

- Speed Anatomy (quiz): Quizappen konsentrerer seg om anatomi og ber deg simpelthen om å sette fingeren på organet, knokkelen, ligamentet eller leddet du får oppgitt. Bildene du skal peke på, er nøye og elegant tegnet opp. Om du bommer på målet ditt (for eksempel peker på hodet når du får oppgitt $\mathrm{m}$. pectoralis major), blinker det rette svaret i gult på figuren. Kjapp og enkel pugging! Appen er gratis.

\section{Referanseapper}

Disse appene bruker jeg mest når jeg er i praksis, enten på sykehus eller på legekontor. Dette er apper som fungerer som raske oppslagsverk.

- Legevakthåndboken: Endelig kom den som app! En kjent håndbok som er digitalisert og omgjort til en pen og ryddig applikasjon. Kompakte tekster om symptomer, funn, differensialdiagnoser og tiltak om vanlige tilstander man kan møte. Innholdet er delt inn etter: Når det haster, Symptomer og sykdommer, Skader og Administrative forhold. Dette er veldig praktisk. I tillegg kan du søke gjennom alt innholdet på appen om det er noe spesifikt du leter etter. Appen er gratis (bra!), og du trenger ikke være tilkoblet Internett for å lese innholdet (kjempebra!).

- Felleskatalogen: Dette er utvilsomt en av de mest nyttige norske medisinske appene tilgjengelig i dag - den gode gamle Felleskatalogen, digitalisert. Her kan du søke etter medikamenter, se bilder av piller, legge medisiner til i snarveier, finne nærmeste apotek og selvfølgelig lese alt du vil om medikamenter. Den store fordelen er at appen oppdateres automatisk med jevne mellomrom, og at du sparer tid på å søke opp medikamentet i stedet for å bla $i$ en bok. Appen er dessuten gratis og tilgjengelig uten Internett-tilgang.

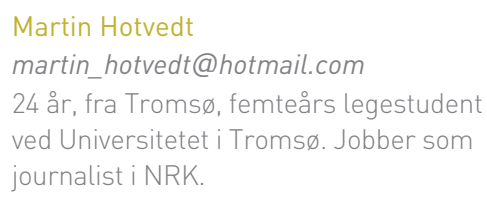

PUBLISERT I BLOGGEN

(b) 21.5.2013

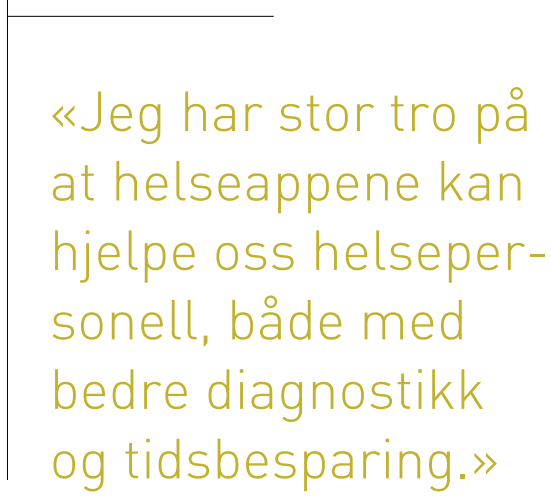

- TurnusABC: Denne norskproduserte og rimelige komplette appen inneholder vanlige tilstander som kan møte deg i akuttmottaket. Her får du symptomer, behandling, differensialdiagnostikk og flere kalkulatorer som er kjekke å ha (GFR, BMI, CHADS2 og så videre) som turnuslege. Gipsteknikk og tips for røntgentolkning følger også med. Dette er en konsis blanding av Turnuslegehåndboka og Metodebok $i$ skadebehandling, i tillegg til noen andre kilder. Ulempen er at den på visse områder ikke går nok i dybden, og at den koster over 100 kroner.

Dette er altså noen av de appene jeg synes fungerer best i dag, fra mitt perspektiv som medisinstudent. Jeg har stor tro på at helseappene kan hjelpe oss helsepersonell, både med bedre diagnostikk og tidsbesparing. Du må imidlertid alltid undersøke om utgiveren er en seriøs aktør.

Om helseapper interesserer deg, vil jeg avslutningsvis slå et slag for den amerikanske nettsiden imedicalapps.com. Her finner du svoert grundige anmeldelser fra helsepersonell av det siste innen mobile helseapper. App-solutt anbefalt!

Kommentarer til og diskusjoner om innlegget finner du på blogg.tidsskriftet.no 